\title{
Social Determinants of Health, Violent Radicalization, and Terrorism: A Public Health Perspective
}

\author{
Héctor E. Alcalá, ${ }^{1, \dagger}, *$ Mienah Zulfacar Sharif, ${ }^{2, \dagger}$ and Goleen Samari ${ }^{3, \dagger}$
}

\begin{abstract}
Background: Terrorism-related deaths are at an all-time high as there were 32,685 and 29,376 terrorism-related deaths in 2014 and 2015, respectively. Terrorism is defined as the use of violence and intimidation in the pursuit of political aims. Terrorism is detrimental for mental health, premature mortality, and economic losses and undermines the central tenets of public health to improve the health and well-being of populations. Despite the impact terrorism has on avoidable morbidity and mortality, population health research largely overlooks social determinants of terrorism and risk factors that contribute to terrorist activities.

Methods: Drawing from what is known about commonly studied social determinants of health topics, including the relationships between structural and interpersonal discrimination, social cohesion, and gang violence and health, we present a public health framework, rooted in the social determinants of health, for identifying potential factors influencing terrorism and violent radicalization.

Results: Social determinants of health provide unique insight into how interpersonal and structural factors can influence risk for violent radicalization and terrorist activity. Each of the topics we review provides an entry point for existing public health and behavioral science knowledge to be used in preventing and understanding violent radicalization and terrorism. For example, anti-Muslim sentiment has promoted discrimination against Muslims, while also serving to marginalize and stigmatize Muslim communities. These conditions limit the social resources, like social cohesion, that Muslims have access to and make political violence more appealing to some.

Conclusions: Public health can contribute much to the ongoing debate around terrorism. The field must take a more prevention-focused approach to the problem of terrorism. Failure to do so only perpetuates approaches that have not been successful.
\end{abstract}

Keywords: discrimination; gang violence; social cohesion; terrorism; United States

\section{Introduction}

Around the world, the death toll due to terrorism has reached unprecedented levels. From 2013 to 2014, there was an $80 \%$ increase in the number of terrorismrelated deaths rising from 18,111 in 2013 to 32,685 in
2014. ${ }^{1}$ However, only $2.6 \%$ of all deaths from terrorism have occurred in the West, and $72 \%$ of terrorismrelated deaths are concentrated in five countriesSyria, Pakistan, Iraq, Nigeria, and Afghanistan. ${ }^{1}$ In addition to premature mortality, terrorism is associated

\footnotetext{
${ }^{1}$ Department of Public Health Sciences, University of Virginia, Charlottesville, Virginia.

${ }^{2}$ Department of Medicine, University of California, Irvine, Irvine, California.

${ }^{3}$ Population Research Center, University of Texas, Austin, Texas.

These three authors contributed equally to this work.
}

*Address correspondence to: Héctor E. Alcalá, PhD, Department of Public Health Sciences, University of Virginia, 560 Ray C. Hunt Drive, Charlottesville, VA 22902, E-mail: hectorapm@ucla.edu

(C) Héctor E. Alcalá et al. 2017; Published by Mary Ann Liebert, Inc. This is an Open Access article distributed under the terms of the Creative Commons Attribution License, which permits unrestricted use, distribution, and reproduction in any medium, provided the original work is properly cited. Mary Ann Liebert, Inc. offers reprint services for those who want to order professionally produced copies of articles published under the Creative Commons Attribution (CC BY) license. To obtain a price quote, email Reprints@liebertpub.com. Please include the articlé title or DOI, quantity, and delivery destination in your email. 
with a myriad of mental health outcomes, including depression, anxiety, and posttraumatic stress disorder (PTSD). ${ }^{2}$ Terrorism-based fear also dissuades travel and reduces consumerism, leading to economic losses. ${ }^{3}$ As such, terrorism is a focus of United States (U.S.) foreign policy, with the U.S. federal government annually spending an average of $\$ 600$ billion for defense and annually increasing counterterrorism spending in a range anywhere from $\$ 17$ to $\$ 60$ billion. ${ }^{4}$

Despite the influence terrorism has on population well-being and political and economic systems, a public health framework for better understanding the risk factors for terrorist activities is lacking. Terrorism is defined as the use of violence and intimidation in the pursuit of political aims. Terrorism is often perpetuated by those who have been violently radicalized. ${ }^{5}$ Violent radicalization means the process of adopting or promoting an extremist belief system for the purpose of facilitating ideologically based violence to advance political, religious, or social change. While public health is largely involved in preparedness strategies and addressing the aftermath of terrorist events, social determinants of terrorism and violent radicalization and risk factors for terrorism are glaringly absent from mainstream population health discourse. This is a shortcoming of public health-given that one of the main goals of the perpetrators is to instill a population level of fear, uncertainty, and vulnerability ${ }^{6}$ and that terrorism undermines the central tenet of public health, namely, to improve the health and well-being of populations and prevent avoidable morbidity and mortality.

Terrorism is not an individual experience; it is violence at a population level and worthy of attention in fields focusing on socioecological understanding of social processes and human behavior. A public health perspective can provide insights on the risk factors for radicalization and social determinants of terrorism. We recognize the unpredictability of terrorist attacks and by no means claim to have identified strategies for "terrorism prevention." Rather, given public health's ecological perspective and unique role in identifying factors that protect or hinder the health of communities, we describe how to use commonly used theories and frameworks to start and disentangle potential risk factors for either promoting and/or engaging in violent terrorist activity.

\section{Methods}

The goal of this article is to incite critical dialogue on how social determinants of health researchers and professionals can advance our understanding of risk factors for radicalization and future tragic terrorist events. A case study from the United Kingdom shows that violent radicalization is an outcome of a complex interaction among social, political, cultural, historical, and interpersonal factors. ${ }^{7}$ This article builds on this work for the U.S. context and explains how a public health understanding of health, namely, the relationship between discrimination, social cohesion, and gang violence and health, can help identify potential risk factors for terrorism from violent radicalization. Then, this review explores future directions for public health, behavioral and social science researchers and practitioners to understand and contribute to research on terrorism and health.

\section{Results}

\section{Discrimination and health}

There is a mounting body of evidence linking discrimination, at multiple levels (individual, as well as institutional) to poor health outcomes and health disparities. ${ }^{2,8,9}$ Perceived discrimination has been associated with an increase in risk factors for physical health, including high blood pressure and substance abuse, and also in physical health outcomes, including hypertension and breast cancer. ${ }^{8}$ However, the most compelling evidence suggests a link between discrimination and mental health outcomes, including depression, anxiety, and psychological distress. ${ }^{10}$

Discrimination is a specific type of stressor that is "uncontrollable and unpredictable."11 The experience of discrimination is associated with the onset of physiological responses to stress that then have longer term implications for health outcomes, including a "wear and tear" impact on regulatory systems as a result of ongoing activation of the allostatic systems. ${ }^{11}$ Over time, discrimination can also erode protective resources, decrease one's engagement in health-promoting behaviors (e.g., cancer screening), as well as increase their engagement in unhealthy behaviors (e.g., substance abuse), explained as maladaptive coping mechanisms to the stressor. ${ }^{8}$

Moreover, scholars argue that "context matters" as it is possible that the relationships (and/or magnitudes) of the effects of discrimination vary by racial and ethnic groups. ${ }^{10,12}$ Or, as Gee et al. ${ }^{12}$ argue, we should not assume a "one race fits all" effect on the relationship of indicators of discrimination on health outcomes. This holds true for many Muslim Americans or those who may be perceived as Muslim Americans (including Sikhs), who have experienced heightened levels of discrimination, post-9/11. ${ }^{13,14}$ This discrimination exists 
despite the fact that many Muslim Americans, who come from the 22 Arab countries of the Middle East and North Africa, are classified as "White" by the categories set forth by the Office of Management and Budget, even though a large proportion of them do not identify as White. ${ }^{15}$ Research on racial and ethnic health disparities among people categorized as White is limited as it is assumed that this category is "racially neutral."15

This disconnect is likely attributed to the rampant xenophobia and heightened levels of Islamophobia in the post-9/11 context. As Rousseau (2011) explains, "...the discourse on security stemming from the war on terror generated suspicions and increased prejudice toward all groups considered a potential threat." Following 9/11, rhetoric within the media and policy realm has disproportionately singled out the Islamic faith and Muslims as evidenced through legislation sanctioning deportation of Muslims and media coverage portraying Arab or Muslim Americans as the "terrorist". ${ }^{16}$ This xenophobic framing fails to acknowledge the small faction of Muslims the perpetrators of these violent acts actually represent and ignores Muslim victims of terrorism. For example, when looking specifically at the victims of Al-Qa'ida, Muslims are seven times more likely to be killed by Al-Qa'ida than nonMuslims ${ }^{17}$ and Muslims represent between $82 \%$ and $97 \%$ of fatalities perpetrated by the Islamic State of Iraq and Syria (ISIS). ${ }^{18}$ In the context of health disparities research, xenophobia and Islamophobia are important forms of discrimination that contribute to health disparities. ${ }^{19}$

Immigration policies contribute to discrimination of Muslims and Middle Eastern Americans. Immigration policies racialize and construct particular groups of immigrants as a threat to the nation's health. ${ }^{9}$ Several policies following $9 / 11$ establish that all immigrants of Middle-Eastern origin should be viewed as potential terror threats and only second as newcomers. ${ }^{20}$ The threat of terrorism has misappropriated immigration laws as a means to promote antiterrorism goals. ${ }^{21}$ Immigrants, particularly from the Middle East, are thus framed as a national security risk, igniting xenophobia and fear of the "Other."22 Immigrant integration is a complex process that is based partially on the reception experience at destination. Many immigrants experience discrimination, oppressive living conditions, and a lack of access to basic services, all of which are known determinants of health. ${ }^{23}$ The discrimination of Muslims and/or Middle Eastern
Americans, largely formed by structural factors like immigration policies, curtails the benefit of racial centrality described as "strength of positive identification with one's racial group," among Muslim and Middle Eastern Americans. ${ }^{24}$ Thus, identifying as Muslim in our current sociopolitical context can be conceptualized more as a stressor than a sense of support and, thereby, be more detrimental as opposed to protective for health and behaviors.

\section{Social cohesion, terrorism, and health}

The ongoing stress related to being viewed as a threat can undermine social cohesion and social capital, both of which are important determinants of population health and preventing community violence. ${ }^{25}$ Thus, pathways to violent radicalization and terrorism can be better understood if health research investigates variables from the social and behavioral sciences like social cohesion and capital. ${ }^{26}$

Social cohesion refers to the extent of connectedness and solidarity among groups in society, including the absence of social conflict and the presence of social bonds. ${ }^{27}$ Social capital is defined as the features of social structures, like levels of interpersonal trust and norms of reciprocity and mutual aid, that act as resources for individuals and facilitate collective action. ${ }^{27}$ Social capital is the resources or trust, norms, and the exercise of sanctions available to members of social groups (a work place, voluntary organization, neighborhood, etc.) and/or the actual resources-social support, information channels, and social credentials that are embedded in social networks. ${ }^{28}$ Social capital can yield social networks that bring people together in at least two different ways: (1) bring people who are alike together (i.e., bonding networks) and (2) bring people who are not alike together (i.e., bridging networks). ${ }^{29,30}$

The presence of oppressive conditions for relationship building among new immigrants may deter the social participation that is crucial for the formation of social capital. Social capital is achieved through the investment in social relations and resources by individuals to enhance their expected returns or expressive actions. ${ }^{31}$ The potential impact of social capital on social cohesion will vary depending on the ways in which its effects are enhanced or diminished by the wider social, political, economic, and cultural environment. ${ }^{22}$ The current social environment is not conducive to fostering social capital and cohesion of Muslim and Arab Americans, because identifying with these respective 
groups leaves people vulnerable to discrimination and excluded from positive social bonds. Coupled with the discrimination faced by Muslims and Arabs in the West, individuals may not have the opportunity to form either bridging or bonding networks due to pressures to distrust individuals like themselves and hostility faced from those who are unlike themselves.

The relationship between social cohesion and health is well established across several indicators of health, including self-rated health, cardiovascular disease, cancer, diabetes, and infectious diseases. ${ }^{32}$ Trust, at the individual and community level, frequently serves as an indicator of social cohesion and then linked to health. Greater social capital is also an important determinant of health and mental health of children, adolescents, adults, and aging populations. ${ }^{28,33}$ Social capital is a means of consolidating resources and protecting against losses like physical health, mental health, and life satisfaction. ${ }^{31}$ The relationship between social capital and health is embedded in the broader social context as socially active individuals report good health in countries with high levels of social capital, but are less likely to do so in countries with low levels of social capital. ${ }^{34}$ Although few studies have sought to directly assess the mechanisms linking social capital to health, a variety of hypothesized pathways have been proposed by which cohesion may affect health, including the diffusion of knowledge about health promotion, promotion of access to local services and amenities, and psychosocial processes which provide affective support and mutual respect. ${ }^{27}$

Low levels of social capital, however, can be risk factors for population health. Prevention of vandalism and violent crime is rooted in collective efficacy. ${ }^{33}$ The link between social capital and violent crime is repeatedly shown. ${ }^{35}$ There is a "dark side" of social capital or the contagion of high risk behaviors within networks like the spread of suicidal ideation ${ }^{36}$ and alcohol and other drug use among adolescents. ${ }^{37}$ Suicide and crime are both related to low levels or absence of social cohesion. ${ }^{32}$ As such, one potential motivator of terrorist-driven suicide bombings and violence could be an indication of a lack of, or low levels of, social cohesion.

\section{Terrorism and gangs}

A useful approach to examining the role that public health and behavioral and social sciences can play to better understanding the etiology of violent radicalization and/or terrorism prevention is to examine another source of organized violence such as gang violence.
Terrorist and gang members have some key similarities. For example, both groups are comprised disproportionately of males, individual members form a collective that supports its members and their actions, both groups attempt to counter the efforts of law enforcement, and both engage in violent acts as a means of social control. ${ }^{38}$ At the individual level, gangs and terrorist organizations appeal to individuals who are psychologically deviant, have limited access to socioeconomic opportunities, or are marginalized members of society. ${ }^{39-44}$ In fact, terrorist groups attract a range of unstable individuals. ${ }^{45}$ Joining these groups provides individuals with group identification and belonging that they cannot find in mainstream society. In addition, group membership for both the terrorist and gang member is a source of power and protection. ${ }^{39}$ Overall, terrorism and gang membership appeal to members of society who are on the margins and view joining either group as a means of obtaining power and/or exercising influence.

There are also characteristics that gangs have that terrorists (or terrorist networks) do not. These include the following: (1) goals with symbolic (and not political) ends; (2) a less rigid organizational structure; (3) shorter periods of cooperation among members; (4) transitory group membership; and (5) a physical space that is identifiable and defendable. ${ }^{46}$ In this study, the key distinction is that the motivations of terrorist groups are political, while those of the gang member are not always. ${ }^{47}$ In addition, much of the understanding of gangs does not view them as transnational actors in the same way that we frequently understand terrorists.

Despite theorized differences between terrorists and gang members, governments have not consistently distinguished between the two, revealing the very subjective, or politicized, nature of the "terrorist" label. For example, in New York, gang related murders have been successfully prosecuted using antiterrorism legislation. ${ }^{48}$ However, subsequent courts ruled that terrorism laws could not be used to prosecute cases of gang violence. ${ }^{49}$ Similarly, the Salvadoran government has labeled the Mara Salvatrucha and Barrio 18 gangs as terrorist groups. ${ }^{50}$ In effect, these actions advance the argument, explicitly and implicitly, that gang activity can serve to "intimidate or coerce" civilians, in the same way that terrorists do. While all of this is occurring, the media amplifies the threat of terrorism perpetrated by Arabs and Muslims, while downplaying and providing excuses for domestic terrorism. ${ }^{24}$ The end result is that the term "terrorist" is applied by 
governments to denote extra condemnation and not necessarily to label specific acts with specific motives. As a result, terrorism becomes hard to define, and thus, harder to study and prevent. In addition, because the distinction between gangs and terrorism is highly subjective, it may be possible to use what we know about the former to address the latter.

\section{Discussion}

This review shows that public health and behavioral science concepts can be applied to our understanding of risk factors for engaging in, or promoting, violent acts of terrorism. Importantly, this work does not condone or justify these acts of violence; instead, we aim to emphasize how existing public health and social science frameworks can do more to understand, and potentially prevent, this epidemic of violence. Specifically, pertinent to a public health perspective on terrorism include discrimination, socialization processes like social cohesion, and other forms of radicalization like gang membership and violence. Prior research consistently demonstrates that individual and structural discrimination are detrimental for population health, and social cohesion and integration are integral for physical and mental health. ${ }^{8,51}$ The following discussion shows how these concepts are salient for a theoretical and empirical understanding of terrorism.

Experiencing discrimination is a marker of social isolation and exclusion, which makes people vulnerable to extremist influences and ideologies while weakening their social cohesion. ${ }^{52}$ Hate crimes against Muslims in the United States remain five times more common since $9 / 11$ than they did before. ${ }^{53,54}$ From reports and opinion polls, we know that hate speech and crimes against Muslim Americans are commonplace. ${ }^{54}$ In addition, Muslim Americans must contend with government surveillance and monitoring, which is associated with anxiety and behavior modification, to avoid contexts that might lead to government suspicion. ${ }^{55}$ This anxiety and behavior modification includes fear of hate crimes, distress about threats to safety, loss of community, isolation, and stigmatization. ${ }^{53}$

As discussed above, immigration policy is also a form of structural discrimination that contributes to social segregation. ${ }^{9}$ Social and economic policy are synonymous with health policy. Therefore, immigration policy fueled by "antiterrorism policy" can be a determinant of health. Although there are well-documented effects that immigration policies have on limiting access to health and social services for immigrants, the idea that those policies also directly impact the social determinants of disease by shaping access to life opportunities is understudied. ${ }^{9}$ The effects of anti-immigrant policies can, thus, be far reaching in their ability to undermine the health of immigrants and their families across the life course. Furthermore, since antiimmigrant policies racialize anyone perceived to be an immigrant, the effects extend to subsequent generations. There is a pattern of racial and religious profiling in the naturalization process to block citizenship of individuals from Muslim countries. ${ }^{16}$ As a result, antiimmigrant sentiments create hostile environments that can compromise health of entire communities.

Discriminatory acts and policies also inhibit other social determinants of health like social cohesion. Young people are particularly vulnerable to radicalizing influences because of isolation, marginalization, and a lack of social capital. ${ }^{56}$ Muslims, specifically, are the object of political scrutiny and the target of negative media discourses. Counterterrorism policies, however well intentioned, can damage social cohesion by isolating a group of people like Muslim Americans ${ }^{25}$ in that they perceive to be "targeted" because of their ethnic and/or religious identity. ${ }^{2}$ For example, the Antiterrorism and Effective Death Penalty Act led to investigation of Muslim American political and social activity and to the deportation of Muslims with links to terrorist activity. ${ }^{20}$ The 2001 Patriot Act extended this legislation and gave the state new powers, including surveillance, which profiles Muslim Americans or "Muslim-like" Americans. ${ }^{20}$ These policies isolate Muslim or Arab Americans, promote discrimination, and create barriers to the health promoting effects of social cohesion.

Feelings of marginalization have been shown to lead to decreased self-worth and, in turn, increase radicalization. ${ }^{57}$ Structural marginalization of a group undermines social cohesion and can lead to fragmentation, including the forming of groups with militant or extremist views, thereby undermining our national security and public health goals. A need for social respect and ties can drive individuals toward radicalization when coupled with one's fear of security and oppression. ${ }^{45}$ Engaging people from all political, religious, and demographic backgrounds is essential to foster cohesion, which prevent individuals from being drawn into extremist groups. Peace psychology has long argued that the promotion of positive intergroup relations is integral to the prevention of violent episodes. ${ }^{58}$ Moreover, peace psychology posits that in 
addition to efforts to prevent incidents of violence, or "negative peace," we must equally emphasize efforts focusing on "positive peace," meaning we must strive toward a more equitable society that is rooted in social, economic, gender and racial justice. ${ }^{59}$ In other words, this holistic view recognizes the importance of addressing underlying factors, related to sense of exclusion, that drive people to extremists, including lack of economic and educational opportunities and trauma resulting from ongoing conflict. ${ }^{60}$

Taken together, a public health perspective can argue that current efforts to tackle terrorism may have, in fact, increased our risk for further violent attacks (Fig. 1). Specifically, anti-terrorism policies have promoted the discrimination of Muslims. In turn, these actions by non-Muslims erode social cohesion in Muslim communities, as Muslims are incentivized to distance themselves and mistrust their peers. As a result, some individuals may become isolated and marginalized. For a small minority, this may make them receptive to radicalization. For fewer still, this may motivate them to engage in acts of terrorism. The government responds to terrorist acts by enacting anti-terrorism policies that fuel discrimination and continues the cycle.

\section{Implications for public health research and practice}

Threats of terrorism operate across borders and require public health attention to globalization and the transnational nature of people. Greater awareness of the negative reverberations for U.S. policies for people around the globe is needed. Thus, although public health training programs emphasize their interdisciplinary focus, courses on U.S. foreign policy and international relations are not included in the common topic areas of focus. Public health training programs should integrate U.S.'s foreign policy into their curricula and emphasize awareness of global events, given the global origins of many of our most critical public health concerns. Specific to foreign policy, it is critical that we, as a field, challenge the systems that implement certain policies, which then result in the anti-U.S. sentiment that can foster radicalization. For example, some have argued that the American-led invasion of Iraq, under the pretense of anti-terrorism, led to the death of thousands of Iraqis and the displacement of millions more and laid the groundwork for the rise of newer terror threats like ISIS. ${ }^{61}$ To truly understand the context of terrorism, multilevel thinking is required-the individual, group, state, and global dynamics. ${ }^{62}$ To take a public health perspective of determinants of terrorism, greater attention needs to be paid to U.S. foreign policy and issues around the world that can ultimately influence public health and national security.

Given the heightened experiences of discrimination and social isolation among immigrations, the global dimension of terrorism also pertains to immigrants. Immigration research increasingly recognizes that immigrants operate in a transnational space. Transnationalism involves the maintenance of occupations or activities that necessarily require regular social contacts

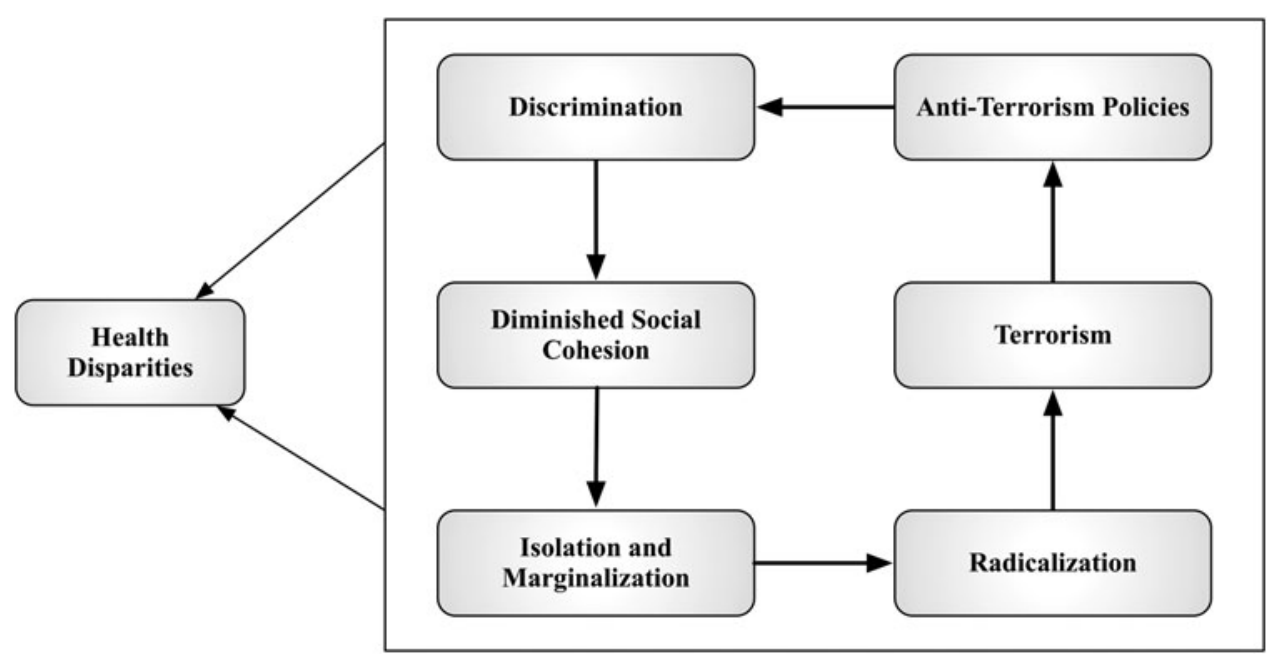

FIG. 1. Public health framework of terrorism and violent radicalization. 
over time, across national borders and/or across cultures. ${ }^{63}$ Transnationalism recognizes that immigrants have ties with their country of origin as they adopt ties in the host country. However, public health and behavioral and social science research often fail to recognize the interaction and integration of people across borders, drawing only on the destination contexts. Implications of transnationalism remain largely untested in health research. Research can be enhanced by considering the context and conditions of both sending and receiving countries to fully understand social determinants of terrorism. Transnationalism and migration-related factors are integral to understanding terrorism. ${ }^{7}$

Given the similarities between terrorism and the problem of gang violence, it may be possible to extend the public health approach that some have advocated for use against gang violence and adopt approaches that have been advocated to curb political violence or terrorism. Briefly this public health approach involves four stages: (1) Describing the problem; (2) Identifying risk and protective factors; (3) Developing and evaluating prevention strategies; and (4) Disseminating prevention strategies. ${ }^{7,64}$ In this study, the focus is on preventing both individuals from joining gangs and preventing gang-related violence and differs radically from the current policing and criminal justice approach toward Muslims in the antiterrorism context that relies heavily on stigmatizing Muslims in the West and can be counterproductive. ${ }^{65}$ In fact, gang prevention and intervention efforts that focus on police suppression are not effective, while efforts focusing on local contexts, gang prevention among youth, and comprehensive community programs tend to show promise. ${ }^{66}$ Furthermore, others have argued that a public health approach to the problem of political violence can involve primary (i.e., preventing violence), secondary (i.e., shortening the duration of violence), and tertiary prevention (i.e., preventing violence from becoming chronic and engaging in rehabilitation and reconstruction). ${ }^{25}$ In this way, strategies to deal with terrorism should be rooted in evidence and science and not politics and fearmongering.

For social cohesion, a potentially effective approach to counterterrorism would include: legal and political efforts that champion human rights for all members of society, embracing the development of cultural literacy approach to community engagement, and affirming the importance of intermediate and long-term relationships between individuals and communities. Interventions should focus on how social exclusion and marginalization can generate grievances that are not processed through political engagement or democratic nonviolent negotiations. ${ }^{52}$ This also has wider health benefits of cohesive communities with greater social capital, economic resources, and fair access to health. Furthermore, efforts must be undertaken to encourage the formation of bonds among Muslims and Arabs in the West and between these groups and others. In this way, the features of social networks can be leveraged to both increase access to outside resources to marginalized groups and promote the internal stock of resources among these groups.

Approaches to reducing radicalization have taken advantage of knowledge of social capital and social networks. For example, Denmark has taken a different approach toward reducing the risk of radicalization in their response to people returning from Syria, whereas other European countries (and the U.S.) impose legal consequences for travelling to Syria. Danish police officers "welcomed" returnees from Syria by offering a psychiatrist or mentor, assistance finding an apartment and returning to school, or "whatever they needed to fully integrate back into society." ${ }^{67}$ This innovative approach toward deradicalization is guided by the idea that "fighting" terrorism through policing and/or "profiling" people will only incite perceived discrimination, humiliation, and/or marginalization, which is what they believe is at the root of the problem and will only make matters worse.

\section{Conclusion}

Adopting a social determinant of health approach to the multifaceted and transnational dimensions of terrorism is not without an array of challenges, including how one goes about "defining" or "identifying" a terrorist. However, given the climate of heightened discrimination toward Muslims and high risk for violent radicalization, social and behavioral scientists are in a unique position to inform and become actively involved in debates and initiatives to understand and address terrorism by applying a social determinant framework. Specifically, we have discussed how literature on discrimination, social cohesion, and gang violence can inform such efforts. These efforts are now more urgent as the current U.S. President had promised policies that target Muslims for increased government scrutiny or prevent Muslims from entering the country as refugees. 


\section{Acknowledgment}

The authors thank Dr. Jennifer Jee-Lyn García for her helpful comments on a draft of this article.

\section{Funding}

The research was supported by the National Institute of Child Health and Human Development grants at the University of Texas at Austin (T32HD007081 and R24HD042849). The content does not necessarily represent the official views of the National Institutes of Health.

\section{Author Disclosure Statement}

No competing financial interests exist.

\section{References}

1. Institute for Economics and Peace. Global Terrorism Index. New York, NY 2015.

2. Rousseau C, Jamil U, Bhui K, et al. Consequences of 9/11 and the war on terror on children's and young adult's mental health: a systematic review of the past 10 years. Clin Child Psychol Psychiatry. 2015;20:173-193.

3. Frey BS, Luechinger S, Stutzer A. Calculating tragedy: assessing the costs of terrorism. J Econ Surv. 2007;21:1-24.

4. Desilver D. U.S. spends over $\$ 16$ billion annually on counter-terrorism. Pew Research Center. 2013. Available at www.pewresearch.org/fact-tank/ 2013/09/11/u-s-spends-over-16-billion-annually-on-counter-terrorism Accessed May 22, 2016

5. Golder B, Williams G. What is 'terrorism'? Problems of legal definition. Univ NSW Law J. 2004;27:270-295.

6. Yehuda R, Hyman SE. The impact of terrorism on brain, and behavior: what we know and what we need to know. Neuropsychopharmacology. 2005;30:1773-1780.

7. Bhui KS, Hicks MH, Lashley M, et al. A public health approach to understanding and preventing violent radicalization. BMC Med. 2012;10:1-8.

8. Williams DR, Mohammed SA. Discrimination and racial disparities in health: evidence and needed research. J Behav Med. 2009;32:20-47.

9. Gee GC, Ford CL. Structural racism and health inequities: old issues, new directions. Du Bois Rev. 2011;8:115-132.

10. Abdulrahim $S$, James $S A$, Yamout $R$, et al. Discrimination and psychological distress: does Whiteness matter for Arab Americans? Soc Sci Med. 2012;75:2116-2123.

11. Pascoe EA, Smart Richman L. Perceived discrimination and health: a meta-analytic review. Psychol Bull. 2009;135:531-554

12. Gee GC, Spencer MS, Chen J, et al. A nationwide study of discrimination and chronic health conditions among Asian Americans. Am J Public Health. 2007;97:1275-1282.

13. Abu-Ras WM, Suarez ZE. Muslim men and women's perception of discrimination, hate crimes, and PTSD symptoms post september 11. Traumatology. 2009;15:48-63.

14. Ahluwalia MK, Pellettiere L. Sikh men post-9/11: misidentification, discrimination, and coping. Asian Am J Psychol. 2010;1:303-314.

15. Abdulrahim $S$. Whiteness and the Arab immigrant experience. Race Arab Am Before After. 2008;9:131-146.

16. Allen C. Islamophobia. Burlington, VT: Ashgate Publishing Ltd. 2010.

17. Helfstein S, Abdullah N, Al-Obaidi M. Deadly vanguards: a study of alQa'ida's violence against muslims. Combating terrorism center at west point. 2009. Available at www.ctc.usma.edu/v2/wp-content/uploads/ 2010/10/deadly-vanguards complete I.pdf Accessed March 23, 2017.

18. US Department of State. National counterterrorism center: annex of statistical information. Washington DC: US Department of State. 2012 Available at www.state.gov/j/ct/rls/crt/2011/195555.htm?goMobile $=0$ Accessed March 23, 2017

19. Samari, G. Islamophobia and public health in the United States. Am J Public Health. 2016;106:1920-1925.
20. Love E. Confronting islamophobia in the United States: framing civil rights activism among Middle Eastern Americans. Patterns Prejudice. 2009;43:401-425.

21. Tumlin KC. Suspect first: how terrorism policy is reshaping immigration policy. Calif Law Rev. 2004;92:1173-1239.

22. Cheong $\mathrm{PH}$, Edwards $\mathrm{R}$, Goulbourne $\mathrm{H}$, et al. Immigration, social cohesion and social capital: a critical review. Crit Soc Policy. 2007;27:24-49.

23. Viruell-Fuentes EA, Miranda PY, Abdulrahim S. More than culture: structural racism, intersectionality theory, and immigrant health. Soc Sci Med. 2012;75:2099-2106.

24. Saeed A. Media, racism and islamophobia: the representation of islam and muslims in the media. Soc Compass. 2007;1:443-462.

25. Husband $C$, Alam Y. Social cohesion and counter-terrorism: a policy contradiction? Portland, OR: Policy Press. 2011.

26. De Jong JT. A public health framework to translate risk factors related to political violence and war into multi-level preventive interventions. Soc Sci Med. 2010;70:71-79.

27. Kawachi I, and Berkman L. Social cohesion, social capital, and health. In: Kawachi I, Berkman L. (eds.) Social Epidemiology. New York, NY, 2000 pp. 174-190.

28. Kawachi I, Subramanian SV, Kim D. Social Capital and Health. New York NY: Springer, 2008

29. Geys B, Murdoch Z. Measuring the "bridging" versus "bonding" nature of social networks: a proposal for integrating existing measures. Sociology. 2010:44:523-540

30. Son J, Lin N. Social capital and civic action: a network-based approach Soc Sci Res. 2008;37:330-349.

31. Lin N, Cook KS, Burt RS. Social Capital: Theory and Research. New Brunswick, NJ: Transaction Publishers, 2001.

32. Kim D, Subramanian SV, Kawachi I. Social capital and physical health. In: Social Capital and Health. Edited by Kawachi I, Subramanian SV, Kim D. New York, NY: Springer New York, 2008, pp. 139-190.

33. Almedom AM, Glandon D. Social capital and mental health. In: Social Capital and Health. Edited by Kawachi I, Subramanian SV, Kim D. New York, NY: Springer New York, 2008, pp. 191-214.

34. Poortinga W. Social capital: an individual or collective resource for health? Soc Sci Med. 2006;62:292-302.

35. Lederman D, Loayza N, Menendez AM. Violent crime: does social capital matter? Econ Dev Cult Change. 2002;50:509-539.

36. Bearman PS, Moody J. Suicide and friendships among American adolescents. Am J Public Health. 2004:94:89-95.

37. Valente TW, Gallaher P, Mouttapa M. Using social networks to understand and prevent substance use: a transdisciplinary perspective. Subst Use Misuse. 2004;39:1685-1712

38. Forst $\mathrm{B}$, Jack R, Greene, et al. Lynch e. Criminologists on Terrorism and Homeland Security. New York, NY: Cambridge University Press, 2011.

39. Turnley JG, Smrcka J. Terrorist Organizations and Criminal Street Gangs: An Argument for an Analogy. Report. Livermore, California: Advanced Concept Group. Sandia National Laboratories, 2002.

40. Spataro A. Why do people become terrorists? A prosecutor's experiences. J Int Crim Just. 2008;6:507-524.

41. Choi S-W, Luo S. Economic sanctions, poverty, and international terrorism: an empirical analysis. Int Interact. 2013;39:217-245.

42. Meierrieks D. Economic determinants of terrorism. In Chatterji M. (ed.) Contributions to Conflict Management, Peace Economics and Development. Bradford, UK: Emerald, 2014, pp. 25-49.

43. Pyrooz DC, Sweeten G. Gang membership between ages 5 and 17 years in the United States. J Adolesc Health. 2015;56:414-419.

44. Freytag A, Krüger JJ, Meierrieks D, et al. The origins of terrorism: crosscountry estimates of socio-economic determinants of terrorism. Eur $J$ Polit Econ. 2011;27:S5-S16.

45. Wagner RV. Terrorism: a peace psychological analysis. J Soc Issues. 2006;62:155-171.

46. Decker S, Pyrooz D. Gangs, terrorism, and radicalization. J Strateg Secur. 2011;4:151.

47. Smith CF, Rush J, Burton CE. Street gangs, organized crime groups, and terrorists: differentiating criminal organizations. Invest Sci J. 2013;5:1-18.

48. Tortoroli C. Gangs of New York are terrorists: the misapplication of the New York antiterrorism statute due to the lack of comprehensive gang legislation. John's L Rev. 2010;84:391.

49. Weissner D. New York State's Top Court Rules Gang Activity Is Not Terrorism. Chatterji M. (ed). Albany, NY: Reuters, 2012 
50. Daugherty A. El salvador supreme court labels street gangs as terrorist groups. insight crime. 2015. Available at www.insightcrime.org/newsbriefs/el-salvador-supreme-court-labels-street-gangs-as-terrorist-groups Accessed May 22, 2016.

51. Berkman LF, Glass T. Social integration, social networks, social support and health. Soc Epidemiol. 2000;1:137-173.

52. Atran S. Genesis of suicide terrorism. Science (New York, NY). 2003;299:1534-1539.

53. Abu-Ras W, Abu-Bader SH. The impact of the September 11, 2001, attacks on the well-being of Arab Americans in New York City. J Muslim Ment Health. 2008;3:217-239.

54. Federal Bureau of Investigation. Uniform Crime Reports. Washington, DC, 2015.

55. O'Connor AJ, Jahan F. Under surveillance and overwrought: American muslims' emotional and behavioral responses to government surveillance. J Muslim Ment Health. 2014;8:95-106.

56. McCauley $C$, Moskalenko $S$. Mechanisms of Political radicalization: pathways toward terrorism. Terrorism Polit Violence. 2008;20: 415-433.

57. Lyons-Padilla S, Gelfand MJ, Mirahmadi $\mathrm{H}$, et al. Belonging nowhere: marginalization and radicalization risk among Muslim immigrants. Behav Sci Policy. 2015;1:1-12.

58. Christie DJ. What is peace psychology the psychology of? J Soc Issues. 2006;62:1-17.

59. Christie DJ, Tint BS, Wagner RV, et al. Peace psychology for a peaceful world. Am Psychol. 2008;63:540.

60. Aubrey M, Aubrey R, Brodrick F, et al. Why young Syrians choose to fight: vulnerability and resilience by violent extremist groups. International Alert. London, United Kingdom. 2016.

61. Rogers P. Blowback: Iraq war to Islamic State. Open Democracy. 2015. Available at www.opendemocracy.net/paul-rogers/blowback-iraq-warto-islamic-state Accessed May 22, 2016.
62. Zimmermann E. Globalization and terrorism. Eur J Polit Econ. 2011;27:S152-S161.

63. Portes A, Guarnizo LE, Landolt P. The study of transnationalism: pitfalls and promise of an emergent research field. Ethn Racial Stud. 1999;22:217-237.

64. McDaniel DD, Logan JE, Schneiderman JU. Supporting gang violence prevention efforts: a public health approach for nurses. Online J Issues Nurs. 2014;19.

65. McDonald B, Mir Y. Al-Qaida-influenced violent extremism, UK government prevention policy and community engagement. J Aggress Confl and Peace Res. 2011;3:32-44.

66. Stinchcomb JB. Promising (and not-so-promising) gang prevention and intervention strategies: a comprehensive literature review. J Gang Res. 2002;10:27-46.

67. Rosin H. How A Danish town helped young muslims turn away from ISIS NPR. 2016. Available at www.npr.org/sections/health-shots/2016/07/15/ 485900076/how-a-danish-town-helped-young-muslims-turn-away-fromisis Accessed October 5, 2016

Cite this article as: Alcalá HE, Sharif MZ, Samari G (2017) Social determinants of health, violent radicalization and terrorism: a public health perspective, Health Equity 1.1, 87-95, DOI: 10.1089/ heq.2016.0016

\section{Abbreviations Used}

ISIS = Islamic State of Iraq and Syria PTSD $=$ posttraumatic stress disorder

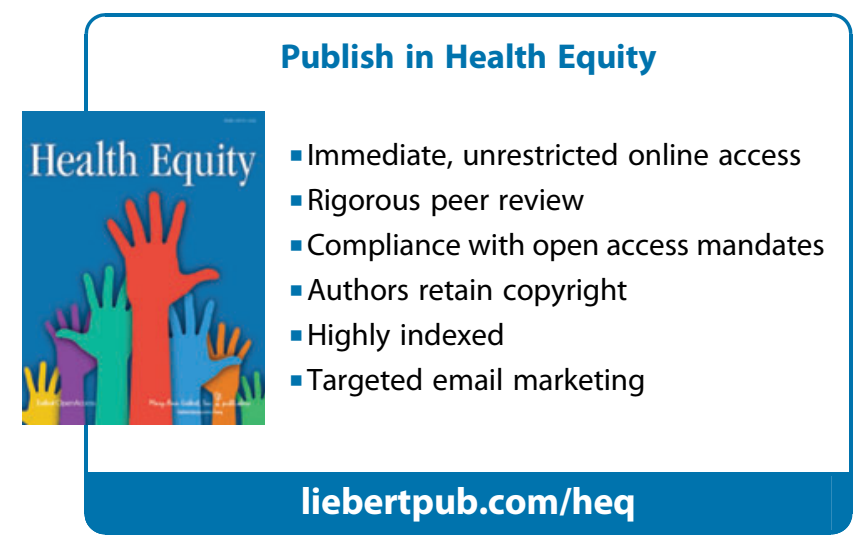

